\title{
Pengaruh berkumur larutan teh hijau dalam menurunkan akumulasi plak pada gigi anak usia 8-10 tahun
}

\author{
${ }^{1}$ Nikhe D. Nubatonis \\ ${ }^{2}$ Paulina N. Gunawan \\ ${ }^{3}$ Jane Wuisan
}

\author{
${ }^{1}$ Kandidat Skripsi Program Studi Pendidikan Dokter Gigi Fakultas Kedokteran \\ ${ }^{2}$ Program Studi Pendidikan Dokter Gigi Fakultas Kedokteran \\ ${ }^{3}$ Bagian Farmakologi dan Terapi Fakultas Kedokteran \\ Universitas Sam Ratulangi Manado \\ Email: nikhedarlietha@gmail.com
}

\begin{abstract}
Oral health is still a major problem in Indonesia. Ignorance towards oral health has lead to accumulation of dental plaques. Children aged 8-10 are susceptible to have dental caries because they like to consume rich-sugar foods. Moreeover, these children are in the process of teeth changes and the growth of new teeth. There are many methods to prevent plaque forming besides tooth brushing inter alia oral rinsing which can cover wider surfaces of the oral cavity. This study was aimed to determine the effect of oral rinsing with green tea solution on reducing dental plaque accumulation among children aged 8-10 years. This was a quasi-experimental study with a pre-test and post-test group design. Population of study was students of SDN 126 Manado aged 8-10 years old. Samples were obtained by using total sampling method. There were 32 participants divided into two groups: rinsing with green tea solution and rinsing with $0.2 \%$ chlorhexidine solution (control group). The paired t-test stated that the accumulation of plaque was decreased after rinsing with green tea solution significantly $(\mathrm{p}=0.001)$. Meanwhile, the $\mathrm{t}$ independent test on green tea solution and chlorhexidine had different scores in reducing plaque accumulation $(\mathrm{p}=0.004)$. Conclusion: Oral rinsing with green tea solution could reduce plaque accumulation in students aged 8-10 years, however, the mean reduction of plaque accumulation after rinsing with green tea solution was less than after rinsing with $0.2 \%$ chlorhexidine solution. Keywords: dental plaque, green tea
\end{abstract}

\begin{abstract}
Abstrak: Masalah kesehatan gigi dan mulut masih menjadi perhatian di Indonesia. Salah satu penyebab ialah terabaikannya kesehatan gigi dan mulut yang mengakibatkan timbulnya akumulasi plak pada gigi. Usia 8-10 tahun sangat rentan terhadap karies karena anak senang mengonsumsi makanan yang mengandung gula. Pada usia ini diperlukan perawatan lebih intensif karena terjadi pergantian gigi dan tumbuhnya gigi baru. Pendekatan pencegahan yang dikenal selain menyikat gigi ialah dengan berkumur yang mencapai lebih banyak permukaan rongga mulut, sehingga efektivitas kontrol plak meningkat. Penelitian ini bertujuan untuk mengetahui pengaruh berkumur dengan larutan teh hijau dalam menurunkan akumulasi plak pada gigi anak berusia 8-10 tahun. Jenis penelitian ialah kuasi-eksperimental dengan pre-test dan post-test group design. Metode pengambilan sampel ialah total sampling Populasi penelitian ialah siswa SDN 126 Manado berusia 8-10 tahun dengan 32 orang responden yang dibagi menjadi dua kelompok yaitu kelompok perlakuan dengan larutan teh hijau, dan kelompok kontrol dengan chlorhexidine $0,2 \%$.. Uji t-paired menyatakan antara sebelum dan sesudah berkumur larutan teh hijau terjadi penurunan akumulasi plak yang bermakna $(\mathrm{p}=0,001)$. Berdasarkan uji t-independent larutan teh hijau dan chlorhexidine memiliki penurunan akumulasi plak yang berbeda $(\mathrm{p}=0,004)$. Simpulan: Larutan teh hijau dapat menurunkan akumulasi plak pada siswa berusia 8-10 tahun. Rerata penurunan akumulasi plak gigi berkumur dengan larutan teh hijau lebih kecil daripada berkumur dengan chlorhexidine $0,2 \%$.
\end{abstract}

Kata kunci: plak gigi, teh hijau 
Nubatonis, Gunawan, Wuisan: Pengaruh berkumur larutan...

Kesehatan gigi dan mulut merupakan salah satu masalah dalam bidang kesehatan yang menjadi perhatian bagi tenaga kesehatan. Data yang dikumpulkan dari Riset Kesehatan Dasar (RISKESDAS) 2013 secara komperhensif menunjukkan prevalensi nasional masalah gigi dan mulut adalah 25,9\%. Sebanyak 14 provinsi di Indonesia mempunyai masalah kesehatan gigi dan mulut diatas angka nasional, salah satunya ialah provinsi Sulawesi Utara dengan prevalensi masalah kesehatan gigi dan mulut $31,6 \%{ }^{1}$

Plak merupakan salah satu faktor pendukung yang menjadi penyebab masalah kesehatan gigi dan mulut. Plak gigi adalah suatu lapisan lunak yang terdiri atas kumpulan bakteri yang berkembang biak di atas suatu matriks jika seseorang melalaikan kebersihan gigi dan mulutnya. ${ }^{2}$ Sisa makanan yang tidak dibersihkan dengan metode menyikat gigi yang benar akan terakumulasi menjadi plak pada gigi dan mengakibatkan masalah lebih lanjut seperti terjadinya karies gigi serta masalahmasalah periodontal lainnya, seperti gingivitis dan periodontitis kronis. ${ }^{3}$

Usia 8-10 tahun merupakan kelompok usia yang rentan terhadap terjadinya karies dan masa transisi gigi susu ke gigi permanen. Pada usia ini diperlukan perawatan lebih intensif karena terjadi pergantian gigi dan tumbuhnya gigi baru. Anak-anak senang mengonsumsi jajanan yang mengandung gula, seperti biskuit, permen, es krim, dan lain-lain yang dapat mempercepat terjadinya karies gigi. Kurangnya pengetahuan anak mengenai kesehatan gigi dibanding orang dewasa memengaruhi mereka dalam membersihkan gigi. ${ }^{4}$ Oleh karena itu upaya preventif pada anak diperlukan untuk mengurangi masalah kesehatan gigi dan mulut.

Cara preventif yang paling dikenal selain menyikat gigi ialah berkumur. Menurut Rawlinson ${ }^{5}$ penggunakan obat kumur praktis digunakan dan dapat menghilangkan bakteri maupun plak di sela-sela gigi yang tidak terjangkau oleh sikat gigi. Berkumur dengan obat kumur juga dapat mencapai lebih banyak permukaan-permukaan rongga mulut, sehingga efektivitas kontrol plak meningkat. ${ }^{6}$

Seiring dengan berjalannya waktu, penelitian-penelitian telah dilakukan dan ditemukan teh yang memiliki potensi sebagai obat pencegah penyakit gigi dan mulut. Penelitian Anggayanti ${ }^{7}$ di Denpasar menyata-kan berkumur dengan teh hitam lebih efektif dari pada chlorhexidine gluconate $0,2 \%$ untuk menurunkan akumulasi plak gigi. ${ }^{7}$ Selain teh hitam, teh hijau memiliki kandungan katekin (senyawa polifenol) yang terbukti memiliki sifat antimikroba, antikariogenik dan efek terapeutik terhadap beberapa penyakit. ${ }^{8}$ Teh hijau juga terbukti efektif terhadap penyakit periodontal, kanker mulut, halitosis dan mencegah karies gigi. ${ }^{9}$

Penelitian ini bertujuan untuk mengetahui apakah berkumur dengan larutan teh hijau dapat menurunkan akumulasi plak pada gigi anak usia 8-10 tahun.

\section{BAHAN DAN METODE PENELITIAN}

Jenis penelitian ini ialah eksperimental semu dengan menggunakan desain pre test dan post test group. Penelitian dilaksanakan di SD Negeri 126 Manado. Responden dipilih berdasarkan metode total sampling pada siswa SD Negeri 126 Manado yang berusia 8-10 tahun dan didapatkan responden sebanyak 32 orang (8 laki-laki dan 24 perempuan).

Variabel penelitian ialah larutan teh hijau dan plak gigi. Teh hijau yang digunakan dalam bentuk teh celup. Dibuat dengan cara menyeduh $8 \mathrm{~g}$ (4 kantung) teh celup hijau dengan aquades $320 \mathrm{ml}$ sehingga diperoleh larutan teh hijau 2,5\%. Proses penyeduhan dilakukan pada temperatur optimum yaitu $70-80^{\circ} \mathrm{C}$ agar kadar polifenol dalam teh tidak berkurang.

Prosedur penelitian dimulai dengan pemeriksaan plak awal sebelum intervensi berkumur menggunakan larutan disclosing solution dengan instrumen indeks plak yaitu Patient Hygiene Performance Index (PHP-Index). Responden dibagi menjadi 2 kelompok yaitu kelompok perlakuan 
berkumur larutan teh hijau dan kelompok kontrol berkumur chlorhexidine 0,2\%. Proses berkumur dilakukan selama 30 detik kemudian skor indeks plak diukur kembali.

\section{HASIL PENELITIAN}

Tabel 1 memperlihatkan data akumulasi plak gigi sebelum dan sesudah perlakuan dengan uji normalitas Shapiro-Wilk yang menunjukkan data terdistribusi secara normal $(\mathrm{p}>0,05)$.

Tabel 1. Uji normalitas Saphiro-Wilk

\begin{tabular}{cccc}
\hline Kelompok & n & p & Ket \\
\hline Perlakuan pre & 16 & 0,347 & normal \\
Perlakuan post & 16 & 0,058 & normal \\
\hline
\end{tabular}

Tabel 2 memperlihatkan hasil uji $t$ paired untuk mengetahui pengaruh larutan teh hijau terhadap penurunan akumulasi plak gigi berdasarkan nilai rerata antara sebelum dan sesudah perlakuan. Rerata sebelum berkumur dengan larutan teh hijau 2,80 $\pm 1,4$ dan rerata sesudah berkumur dengan larutan teh hijau 1,71 $\pm 0,9$; terjadi penurunan dengan selisih sebelum dan sesudah 1,09 $\pm 0,6$. Hasil analisis menunjukkan terdapat perbedaan bermakna antara data akumulasi plak sebelum dengan data akumulasi plak sesudah berkumur larutan teh hijau ( $\mathrm{p}=0,001)$.

Tabel 2. Uji t-paired rerata akumulasi plak gigi sebelum dan sesudah perlakuan berkumur dengan larutan teh hijau

\begin{tabular}{ccccc}
\hline $\begin{array}{c}\text { Teh } \\
\text { Hijau }\end{array}$ & n & $\begin{array}{c}\text { Rerata } \\
\text { akumulasi } \\
\text { plak }\end{array}$ & Selisih & $\begin{array}{c}\text { Nilai } \\
\mathbf{p}\end{array}$ \\
\hline $\begin{array}{c}\text { Sebelum } \\
\text { Sesudah }\end{array}$ & 16 & $\begin{array}{c}2,80 \pm 1,4 \\
1,71 \pm 0,9\end{array}$ & $1,09 \pm 0,6$ & 0,001 \\
\hline
\end{tabular}

Tabel 3 memperlihatkan hasil uji $t$ independent rerata penurunan akumulasi plak kelompok kontrol dan kelompok perlakuan. Penurunan akumulasi plak gigi kelompok perlakuan dengan larutan teh hijau 1,09 $\pm 0,6$ dan rerata penurunan akumulasi plak gigi kelompok kontrol chlorhexidine 0,2\% 1,69 $\pm 0,5$. Hasil analisis menunjukkan terdapat perbedaan bermakna antara data penurunan akumulasi plak kelompok perlakuan dan kelompok kontrol $(\mathrm{p}=0,04)$. Penurunan akumulasi plak kelompok perlakuan berkumur dengan larutan teh hijau lebih kecil daripada kelompok kontrol berkumur dengan chlorhexidine $0,2 \%$.

Tabel 3. Uji independent T-test rerata penurunan akumulasi plak kelompok kontrol dan kelompok perlakuan

\begin{tabular}{ccccc}
\hline Kelompok & $\mathbf{N}$ & $\begin{array}{c}\text { Rerata } \\
\text { penurunan } \\
\text { akumulasi plak }\end{array}$ & SB & p \\
\hline Perlakuan & 16 & 1,09 & 0,6 & 0,004 \\
Kontrol & 16 & 1,69 & 0,5 & 0 \\
\hline
\end{tabular}

\section{BAHASAN}

Data akumulasi plak gigi sebelum dan sesudah perlakuan pada masing-masing kelompok diuji normalitasnya dengan menggunakan uji Shapiro-Wilk (Tabel 4) menunjukkan bahwa semua data terdistribusi normal sehingga dapat dilanjutkan dengan uji parametrik, yaitu uji $t$-paired.

Uji t-paired (Tabel 5) dilakukan untuk melihat ada tidaknya pengaruh berkumur larutan teh hijau pada penurunan akumulasi plak. Hasil analisis data menunjukkan nilai $\mathrm{p}=0,001 \quad(\mathrm{p}<0,05)$ yang artinya terdapat perbedaan bermakna antara data akumulasi plak sebelum dan sesudah berkumur larutan teh hijau, sehingga dapat dikatakan berkumur dengan larutan teh hijau memiliki pengaruh dalam menurunkan akumulasi plak.

Uji t-independent (Tabel 6) dilakukan untuk melihat perlakuan yang lebih baik dalam menurunkan akumulasi plak. Pada kelompok perlakuan rerata penurunan akumulasi plak sebesar $1,09 \pm 0,6$; pada kelompok kontrol rerata penurunan

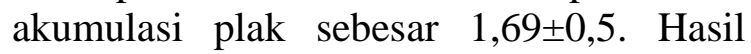
analisis menggunakan uji t-independent menunjukkan nilai $\mathrm{p}=0,004(\mathrm{p}<0,05)$ yang artinya terdapat perbedaan bermakna antara penurunan akumulasi plak kelompok perlakuan dan kelompok kontrol. Data menunjukkan penurunan akumulasi plak kelompok perlakuan berkumur larutan teh hijau lebih kecil daripada kelompok kontrol 
berkumur chlorhexidine $0,2 \%$.

Pada kelompok perlakuan digunakan larutan teh hijau 2,5\%. Teh hijau memiliki senyawa polifenol yang sebagian besar terdiri dari katekin. Katekin dari teh hijau ini bekerja menghambat aktifitas enzim glikotransferase sehingga menghambat perlekatan bakteri dengan pelikel dan proses pembentukan plak juga terhambat. ${ }^{10}$ Polifenol juga bekerja menghambat pertumbuhan mikroorganisme karena mempunyai kemampuan denaturasi protein sel dan merusak membran sel mikroorganisme pada plak gigi. ${ }^{7}$ Penelitian yang dilakukan oleh Wijaya dan Samad ${ }^{11}$ mendapatkan bahwa Konsentrasi Hambat Minimum (KHM) larutan teh hijau terhadap Streptococcus mutans ialah 2,5\%. Penelitian yang dilakukan oleh Awadala ${ }^{12}$ menyatakan bahwa berkumur dengan larutan teh hijau tanpa gula menghambat pertumbuhan bakteri Streptoccocus mutans pada plak dan saliva yang merupakan bakteri utama penyebab karies gigi. ${ }^{12}$ Penelitian lain tentang teh hijau yang dilakukan oleh Fajriani $^{13}$ di Makassar menyatakan berkumur dengan 2,5\% larutan teh hijau memiliki efektivitas yang sama dengan chlorhexidine $0,2 \%$ dalam mengurangi koloni Streptococcus mutans pada saliva secara in vitro.

Hasil penelitian ini menunjukkan rerata penurunan akumulasi plak berkumur chorhexidine $0,2 \%$ lebih besar daripada berkumur larutan teh hijau. Chlorhexidine gluconate $0,2 \%$ yang merupakan obat kumur gold standard, telah terbukti sebagai bahan antiplak sehingga dipilih sebagai pembanding. ${ }^{14}$ Hambatan pertumbuhan plak oleh chlorhexidine dihubungkan dengan sifatnya membentuk ikatan dengan komponen-komponen pada permukaan gigi. Ikatan tersebut akan meningkatkan permeabilitas dinding sel bakteri yang menyebabkan efek bakteriostatik ataupun efek bakterisid mikroorganisme pada plak gigi. ${ }^{15}$ Rerata penurunan akumulasi plak berkumur larutan teh hijau lebih kecil dibandingkan berkumur chlorhexidine $0,2 \%$, mungkin dikarenakan konsentrasi yang digunakan untuk larutan teh hijau hanya 2,5\%. Meningkatkan konsentrasi larutan teh hijau atau menggunakan ekstrak daun teh hijau agar kandungan katekin yang dihasilkan lebih besar bisa menjadi bahan pertimbangan penelitian selanjutnya.

\section{SIMPULAN}

Dari hasil penelitian dan bahasan dapat disimpulkan bahwa berkumur larutan teh hijau memiliki pengaruh dalam menurunkan akumulasi plak pada gigi anak usia 810 tahun. Rerata penurunan akumulasi plak gigi pada kelompok perlakuan berkumur larutan teh hijau lebih kecil dari pada kelompok kontrol yang berkumur dengan chlorhexidine $0,2 \%$

\section{SARAN}

Perlu dilakukan penelitian lebih lanjut untuk mengetahui pengaruh berkumur larutan teh hijau dengan konsentrasi berbeda dan ekstrak daun teh hijau terhadap penurunan akumulasi plak gigi.

\section{DAFTAR PUSTAKA}

1. Riset kesehatan dasar. Jakarta: Badan Penelitian dan Pengembangan Kesehatan Kementrian Kesehatan RI, 2013; p.111.

2. Putri MH, Herijulianti E, Nurjannah N. Ilmu Pencegahan Penyakit Jaringan Keras dan Jaringan Pendukung Gigi. Jakarta: EGC, 2013; p. 56-62,101-7.

3. Anitasari S. Hubungan frekuensi menyikat gigi dengan tingkat kebersihan gigi dan mulut siswa sekolah dasar negeri di Kecamatan Palaran Kotamadya Samarinda provinsi Kalimantan Timur. Dentika. 2005;10:22-7.

4. Rosidi A, Haryani S, Adimayanti E. Hubungan antara konsumsi makanan kariogenik dengan kejadian karies gigi pada anak SDN 1 Gogodalem Kec. Bringin Kab. Semarang. Ungaran: Akper Ngudi Waluyo; 2013: p. 1-7.

5. Rawlinson A, Pollington S, Walsh TF, Lamb DJ, Marlow I, Haywood J, Wright P. Efficacy of two alcoholfree cetylpyridinium chloride mouthwashes - a randomized double blind crossover study. J Clin Periodontol. 2008;35:230-5. 
6. Patabang WA, Leman MA, Maryono J. Perbedaan jumlah pertumbuhan koloni bakteri rongga mulut sebelum dan sesudah menggunakan obat kumur yang mengandung chlorheksidine. Jurnal Ilmiah Farmasi. 2016;5(1):26-31.

7. Anggayanti NA, Adiatmika IPG, Adiputra N. Berkumur dengan teh hitam lebih efektif daripada chlorhexidine gluconate $0,2 \%$ untuk menurunkan akumulasi plak gigi. Jurnal PDGI. 2013;6(2):35-40.

8. Taylor PW, Miller JMTH, Stapleton PD. Antimicrobial properties of green tea catechins. Europe PMC Funders Group. 2005;2:71-81.

9. Arab H, Maroofian A, Golestani S, Shafaee H, Sohrabi K. Review of the therapeutic effects of camellia sinensis. Plants Res. 2011;5(23): 5465-9.

10. Tehrani MH, Asghari G, Hajiahmadi M. Comparing Streptoccocus mutans and Lactobacillus colony count changes following green tea mouth rinse or sodium fluoride mouth rinse use in children. [online]. 2011. [cited 9 July 2016]. Available from URL: http://www.ncbi.nlm.nih.gov/pmc/arti cles/PMC3556286

11. Wijaya D, Samad R. Daya hambat teh hitam, teh hijau, dan teh oolong terhadap pertumbuhan Streptococcus mutans. Jurnal PDGI. 2004;55:82-7.

12. Awadala HI, Ragab MH, Bassuoni MW, Fayed MT, Abbas MO. A pilot study of the role of green tea use on oral health. Int $\mathbf{J}$ Dent Hyg. 2011;9(2):110-6.

13. Fajriani, Andriani JN. Reduction of salivary streptococcus mutans colonies in children after rinsing with $2.5 \%$ green tea solution. Journal of Dentistry Indonesia. 2014;21(3):81-6.

14. Balagopal S, Radhika Arjunkumar R. Chlorhexidine: the gold standard antiplaque agent. J Pharm Sci Res. 2013;12(5):270-4.

15. Sajjan P, Laxminarayan N, Kar PP, Sajjanar R. Chlorhexidine as an Antimicrobial Agent in Dentistry - A Review. OHDM. 2016;15(2):93-100. 